\title{
STANDING-STOCK BIOMASS AND DIVERSITY OF Caulerpa (Chlorophyta) IN SOLONG-ON, SIQUIJOR ISLAND, PHILIPPINES
}

\author{
${ }^{1}$ J.C. Emmanuel G. Llamas, ${ }^{1}$ Lilibeth A. Bucol and ${ }^{2}$ Billy T. Wagey \\ ${ }^{1}$ Department of Biology, College of Arts and Sciences, Negros Oriental State University, \\ Dumaguete City, Philippines \\ ${ }^{2}$ Faculty of Fisheries and Marine Science, Department of Marine Science, Sam Ratulangi \\ University, Manado, North Sulawesi, Indonesia. \\ Corresponding author: billywagey@unsrat.ac.id; bwagey@yahoo.com
}

\begin{abstract}
ABSTRAK
Spesies Caulerpa yang tumbuh di perairan dangkal sampai dilaut dalam dianggap sebagai gangguan ekonomi dan penting. Meskipun invasif di daerah beriklim sedang, spesies Caulerpa terutama $C$. racemosa dan $C$. lentillifera (lato) dipanen dan dikonsumsi sebagai makanan, terutama di Filipina. Komunitas Caulerpa di Solong-on, Siquijor adalah salah satu sumber untuk ekspor ke kota tetangga. Penelitian ini bertujuan untuk menentukan stok tegakan biomassa saat ini, prosentase dan keragaman Caulerpa di Solong-on, serta untuk menentukan parameter lingkungan yang dapat mempengaruhi kelimpahan dan keragamannya. Hasil penelitian menunjukkan total delapan spesies Caulerpa diidentifikasi di komunitas Caulerpa dangkal di Solong-on, Siquijor. Biomasa yang memiliki stok tertinggi diperoleh oleh $C$. cupressoides dengan biomassa rata-rata $26,16 \pm 2,44$ (SE) g berat kering $/ \mathrm{m}^{-2}$, sedangkan $C$. microphysa memiliki biomassa stok yang berdiri paling sedikit dengan rata-rata $9,16 \pm 0,26 \mathrm{~g}$ berat kering $/ \mathrm{m}^{-2}$. Secara umum, total biomassa stok berdiri untuk semua spesies yang diperoleh selama periode sampling adalah $132,57 \pm 2,06 \mathrm{~g}$ berat kering $/ \mathrm{m}^{-2}$. Indeks keragaman Shannon-Wiener $(\mathrm{H}$ ') berkisar dari 1,7-2 yang menunjukkan komunitas Caulerpa yang relatif beragam. Analisis korespondensi kanonik (CCA) mengungkapkan bahwa suhu dan jenis substrat adalah pendorong utama biomassa Caulerpa.

Kata Kunci: biomassa, Caulerpa, tutupan, makroalga, parameter fisika-kimia
\end{abstract}

\begin{abstract}
Caulerpa species growing on shallow to deep waters are considered to be both economically nuisance and important. Although invasive in the temperate regions, Caulerpa species mainly $C$. racemosa and $C$. lentillifera (lato) are harvested and consumed as food, especially in the Philippines. Caulerpa communities in Solong-on, Siquijor are one of the sources for export to neighbouring municipalities. This study aimed to determine the present standing stock biomass, percent cover and diversity of Caulerpa in Solong-on, as well as to determine the environmental parameters that may affect its abundance and diversity. The results showed a total of eight species of Caulerpa were identified in the shallow Caulerpa community in Solong-on, Siquijor. The highest standing stock biomass was obtained by $C$. cupressoides with mean biomass of $26.16 \pm 2.44$ (SE) g dry wt $\mathrm{m}^{-2}$, whereas $C$. microphysa has the least standing stock biomass with an average mean of $9.16 \pm 0.26 \mathrm{~g}$ dry $\mathrm{wt}^{-2}$. In general, the total standing stock biomass for all species obtained throughout the sampling period was $132.57 \pm 2.06 \mathrm{~g}$ dry wt $\mathrm{m}^{-2}$. Shannon-Wiener diversity index $\left(\mathrm{H}^{\prime}\right)$ ranged from 1.7-2 suggesting a relatively diverse Caulerpa community. Canonical correspondence analysis (CCA) revealed that temperature and type of substrate were the main drivers of Caulerpa biomass.
\end{abstract}

Key Words: biomass, Caulerpa, cover, macroalgae, physic-chemical parameters 


\section{INTRODUCTION}

The genus Caulerpa (Family Caulerpaceae) of Chlorophyta is distributed worldwide from the tropical to temperate marine habitats with about 97 species, of which 63 species identified in the Philippines (Guiry \& Guiry 2018). They grow on sandy rock bottoms in the upper sublittoral zone of tropical coral reefs (Nagappan \& Vairappan 2013).

Although certain Caulerpa species (e.g., C. taxifolia, C. racemosa) became invasive in the Mediterranean Sea (Boudouresque et al 1995; Jousson et al 1998; Thibaut et al 2004; Klein \& Verlaque 2008; Cebrian \& Ballesteros 2009), some species (e.g. C. racemosa and C. lentillifera) are native and considered delicacies in the Philippines, Indonesia, Malaysia, and Japan (Nagappan \& Vairappan 2013). Caulerpa, together with other macroalgae, promise to yield economic benefit once maricultured intensively in the Philippines (Cordero 1990). Due to its demand, culture of these varieties in shallow tidal ponds was initiated over years ago in Mactan Island, Cebu and distributed widely in the Philippines, even exported to Japan and Taiwan (Nagappan \& Vairappan 2013). In Siquijor Island, $C$. racemosa (locally known as lato) has been harvested and supplied to Dumaguete City since the 1980s (Calumpong 1984). However, there was a decline in the local harvest of C. racemosa based on the 1984 baseline study of Wagey \& Bucol (2014).

Many studies have been conducted to determine the abundance and species diversity of Caulerpa around the world (Terrados \& Ros 1995; Thibaut et al 2004; Verlaque et al 2004; Schembri et al 2015; Aplikioti et al 2016). Moreover, the focus on these studies were mainly on the invasiveness of the species (Cebrian \& Ballesteros 2009; Bouiadjra et al 2010; Cevik et al 2007; Schembri et al 2015; Aplikioti et al 2016). Apart from an initial study on the standing stock of Caulerpa racemosa at Siquijor Island (Calumpong 1984), no similar study has been done.

This study generally aimed to determine the standing stock biomass, percent cover and diversity of Caulerpa species present in Solong-on, Siquijor, Philippines. In particular, this research aimed to: (1) determine the standing stock biomass (g dry wt. $\mathrm{m}^{-2}$ ) and percent cover of Caulerpa species; (2) determine the diversity of Caulerpa species; and (3) determine the environmental parameters (e.g. salinity, $\mathrm{pH}$, water temperature, and types of substrate) in the study area that may have influenced the abundance and diversity of Caulerpa.

\section{MATERIAL AND METHOD}

\subsection{Description of the study area}

The study was carried out in the intertidal and upper subtidal zone of Solongon $\left(9^{\circ} 11^{\prime} 55^{\prime \prime} \mathrm{N}, 123^{\circ} 27^{\prime} 38^{\prime \prime} \mathrm{E}\right)$, Municipality of Siquijor, Siquijor Island, Philippines. The total land area of the municipality is 90.70 $\mathrm{km} 2$ while the overall shallow marine ecosystem (below $30 \mathrm{~m}$ deep) has an estimated area of 1,035 ha. This marine ecosystem comprised of 175 ha of coral reef (slope and crest combined), 636 ha of seagrass beds, and about 90 ha of Caulerpa racemosa (lato) communities. Eleven species of Caulerpa grow abundantly on northwestern side, particularly in the adjacent barangays of Pasihagon, Tambisan, and Cang-alwang, where the substrate is generally muddy. Substrate also includes limestone platform, broken limestone with mud and rubble, mud, and fine silty sand extending to the seagrass community. Mangrove community is also present dominated by the reforested Rhizophora species.

\subsection{Sampling Design and Sampling Procedures}

Systematic sampling design was adapted in this study because three transect lines were established at equal intervals. Furthermore, a total of ten quadrats were established in each transect lines at equal intervals. Sampling covered three months, once every month, starting from November 2017 until January 2018. One day was allotted for the collection of samples. Transect-quadrat method was used to provide both destructive and non-destructive way of quantifying the biomass and percent cover, as well as the qualitative and quantitative description of the species of Caulerpa along the intertidal and upper subtidal zone of Solong-on, Siquijor. The survey was guided 
by the general procedure for the establishment of transect line by English et al (1997). Three replicate transects were established with a nylon transect line measuring 200-m perpendicular to the mangrove line. Each transect had a $150-\mathrm{m}$ intervals parallel to each other. A $25-\mathrm{cm} x$ $50-\mathrm{cm}$ quadrat was laid along each transect lines with an interval of $20 \mathrm{~m}$ (Calumpong 1984). Furthermore, a bamboo marker was placed in each quadrat.

After establishment of transect lines and quadrats, the survey on percent cover was conducted using the Braun-Blanquet (BB) cover abundance scale (Mueller-Dombois \& Ellenberg 1974; Short \& Coles 2001) (Table 1). The coverage of all species of Caulerpa within the quadrat was observed directly from above and was roughly estimated. After scoring, the values were converted into abundance using the formula:

Abundance $=$ Sum of B-B scale values/number of occupied quadrats

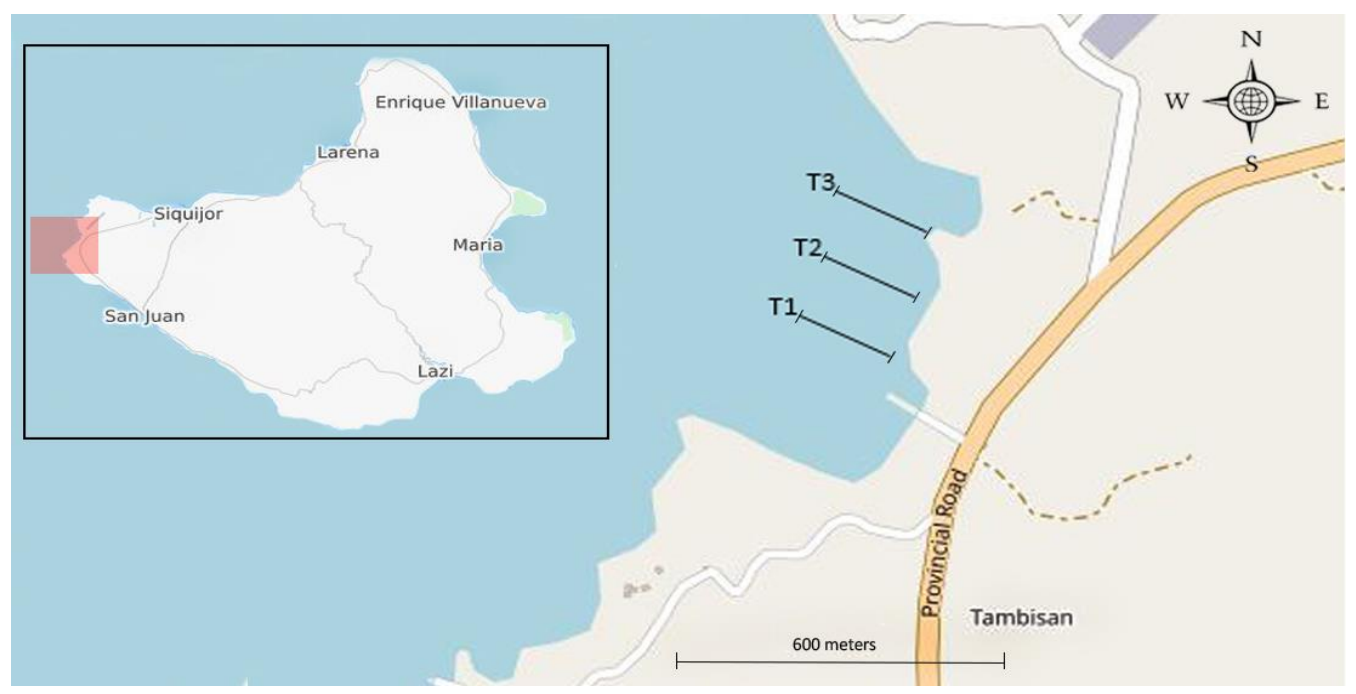

Figure 1. Map of the sampling area showing the transect lines in Solong-on, Barangay Tambisan, Municipality of Siquijor, Siquijor Island. Source: openstreetmap.org

Table 1. Braun-Blanquet scale (adopted from Short \& Coles 2001)

\begin{tabular}{cl}
\hline Class & Cover of the Quadrat \\
\hline 5 & More than 75\% \\
4 & $50-75 \%$ \\
3 & $25-50 \%$ \\
2 & $5-25 \%$ \\
1 & Numerous, but less than 5\% cover or scattered with cover up to 5\% \\
0.5 or + & Few, with small cover \\
0.1 or $r$ & Solitary, with small cover \\
\hline
\end{tabular}

Caulerpa species were identified based on available field guides and taxonomic references: "Field Guide and Atlas of the Seaweed Resources of the Philippines" by Trono (1997) and "The
Genus Caulerpa from Central Visayas, Philippines" by Meñez \& Calumpong (1982). Identification of samples was solely based on its morphological features. In addition, photographs of representative, 
fresh, Caulerpa samples were sent to Dr. Stefano Giovanni Angelo Draisma of the Faculty of Science, Prince of Songkla University for confirmation.

Within each quadrat, above-ground samples were carefully removed using a pair of scissors or knife, excluding the substrate. The samples were placed inside pre-labeled net bags. The samples were transported at the Biology Laboratory of Negros Oriental State University (NORSU), Main Campus I in Dumaguete City. Collected samples were later sorted to species. Samples were cleaned of all debris, epiphytes, and sediments (Thibaut et al 2004; Manas et al 2015). The samples were air dried for 3-5 days, then placed in labeled aluminum foils and placed inside an oven for drying at $80^{\circ} \mathrm{C}$ for 8 hours. The samples were kept inside the oven overnight. The biomass of each Caulerpa species was expressed as g dry wt. $\mathrm{m}^{-2}$ (Terrados \& Ros 1995; Thibaut et al 2004; Iveŝa et al 2006; Qari 2017). Above-ground biomass represents the standing crop biomass (Calumpong 1984). The dried samples were weighed using an analytical balance at the nearest five decimal places. The dry weight biomass was then expressed as g dry wt $\mathrm{m}-2$. The following physico-chemical parameters were measured every sampling: salinity was measured using a hand-held refractometer, salinity for each transect lines was recorded. A drop of about $1 \mathrm{~mL}$ was placed on the daylight plate of the refractometer; $\mathrm{pH}$ using a Vertigrow LCD Digital $\mathrm{pH}$ Water Meter Tester Pen Type; water temperature was recorded using a glass thermometer (with three readings); and types of substrate using standard grab collection with scoop was adopted for the collection of surface sediments (Taft \& Jones 2001; U.S. Army Corps of Engineers Jacksonville District 2009). The scoop was placed into the sediment for about 6 inches deep and about $150 \mathrm{~g}$ of sediment samples were collected and transferred inside pre-labeled plastic bags. The samples were processed for the determination of grain size. Prior to sieving, samples were air dried for 4-5 days, or until completely dried. Sieving took place using different available mesh sieve sizes. The collected sieved samples were identified based on its particle size range using the Wentworth Grade Scale as described by English et al (1997).

\subsection{Data Analysis}

\section{Abundance (Standing Stock Biomass)}

Differences between the biomass between transect and sampling months were statistically tested using Two-Way Analysis of Variance with repeated measures (RMANOVA) in PAST3 (v3.1) software (Hammer et al 2001). Prior to the analysis, using the packages nortest, car and MASS in R Studio (v1.1.419) (RStudio Team 2015), preliminary tests were performed to check for normality of data (Anderson-Darling normality test and QQ-plot) as well as evaluating homoscedasticity and assessing outliers. Values were $\log (\mathrm{x}+1)$ transformed to meet parametric assumptions of ANOVA.

\section{Diversity of Caulerpa species}

Species diversity for each transect was calculated using the Shannon-Wiener Diversity Index $\left(\mathrm{H}^{\prime}\right)$ :

$$
H^{\prime}=-\sum_{i=1}^{s} \frac{n i}{N} \ln \frac{n i}{N}
$$

Where, $\mathrm{H}^{\prime}=$ value of Shannon-Wiener Diversity Index, ni = biomass in the ith species, $\mathrm{N}=$ total biomass, $\mathrm{ln}=$ natural logarithm and $\mathrm{s}=$ number of species in community

\section{Environmental Parameters in Relation to Abundance and Diversity}

To determine the influence of the environmental parameters (water temperature, salinity, $\mathrm{pH}$ and types of substrate) on the biomass of Caulerpa species, the multivariate Canonical Correspondence Analysis (CCA) using the PAST3 (v3.1) was used. This multivariate method was a direct gradient analysis that provided: (1) simultaneous representation of sampling sites, environmental variables and species centroids in a reduced ordination space of orthogonal axes, and (2) an integrated description of speciesenvironment relationships by assuming a common response (as a unimodal distribution) of all species to a set of underlying environmental gradients (Ter Braak 1986). 


\section{RESULTS}

A total of eight species of Caulerpa were observed in the intertidal and upper subtidal zone of Solong-on, Siquijor throughout the sampling period. As shown in Figure 2, the species obtaining the highest standing stock biomass of Caulerpa was $C$. cupressoides with mean biomass of $26.16 \pm 2.44$ (SE) g dry wt $\mathrm{m}^{-2}$, whereas C. microphysa has the least standing stock biomass with an average mean of $9.16 \pm 0.26$ $\mathrm{g}$ dry wt $\mathrm{m}^{-2}$ (Figure 2). In general, the total standing stock biomass for all species obtained throughout the sampling period was $132.57 \pm 2.06 \mathrm{~g}$ dry wt $\mathrm{m}^{-2}$.

\section{Abundance, Diversity, and Physico- Chemical Parameters}

Figure 3 showed that B-B abundance scale values were consistent throughout the three-month sampling. Using the B-B Abundance Scale, percent cover was converted into abundance. Overall, abundance of Caulerpa was highest in January 2018 (4.07) and lowest in December 2017 (3.7). One-way ANOVA ( $\mathrm{F}=7.099$, d.f. $=2, p=0.5288)$ revealed no significant difference between months. This suggests that percent cover does not depend on months of sampling. However, the limited time of sampling may have contributed to this result.

Throughout the study, water temperature ranged from 34.17 to $35.67{ }^{\circ} \mathrm{C}$ (mean: $35.11{ }^{\circ} \mathrm{C}$ ) and Welch's ANOVA $(p=0.9382)$ revealed no significant difference between months (November to January). Salinity, on the other hand, ranged from 34.8 to $35.1 \mathrm{ppt}$ (mean: $34.99 \mathrm{ppt}$ ) and Welch's
ANOVA ( $\mathrm{p}=0.0713)$ revealed no significant difference between months. Likewise, $\mathrm{pH}$ range from 8.03 to 8.07 (mean: 8.06) and Welch's ANOVA $(p=0.1484)$ revealed no significant difference between months (Table 2). Welch's ANOVA was performed since the monthly data for the environmental variables were of small sample size. Overall, there was no variation found in water temperature, salinity and $\mathrm{pH}$ on the sampling area throughout the sampling period.

Five types of substrates were classified according to the Wenthworth Grade Scale: gravel (14.5\%), coarse sand $(23.9 \%)$, medium sand $(20.1 \%)$, fine sand $(20.6 \%)$, and very fine sand $(21.1 \%)$. Coarse sand obtained the highest mean percentage composition for transect 1 (T1), transect 2 (T2) and transect 3 (T3) with values 25.16 , 23.47 and 23.05 , respectively throughout the sampling period (Figure 4). Meanwhile, gravel had the least mean percentage composition for $\mathrm{T} 1, \mathrm{~T} 2$ and $\mathrm{T} 3$ with values $13.79,14.36$, and 15.26, respectively.

Using the Shannon-Wiener Diversity Index $\left(\mathrm{H}^{\prime}\right)$, the diversity for each transect throughout the sampling period was calculated. Both transect 1 (T1) and transect 3 (3) obtained almost the same $\mathrm{H}^{\prime}$ values throughout the sampling period. However, T3 in the month of November obtained the highest $\mathrm{H}^{\prime}$ value of 2.03. Transect 2 (T2), on the other hand, has the lowest $\mathrm{H}^{\prime}$ value obtained all throughout the sampling period. $\mathrm{T} 2$ obtained the lowest $\mathrm{H}^{\prime}$ value of 1.77 in the month of November. Overall, the Caulerpa in the study site were relatively diverse (Figure 5).

Table 2. Summary of water temperature, salinity, and $\mathrm{pH}$ in the study area in three months of sampling.

\begin{tabular}{llll}
\hline Month & Water Temperature $\left({ }^{\circ} \mathrm{C}\right)$ & Salinity $(\mathrm{ppt})$ & $\mathrm{pH}$ \\
\hline November-2017 & $35.50 \pm 0.58$ & $34.8 \pm 0.44$ & $8.07 \pm 0.03$ \\
December-2017 & $34.17 \pm 0.44$ & $35.1 \pm 0.15$ & $8.07 \pm 0.03$ \\
January-2018 & $35.67 \pm 0.44$ & $35.0 \pm 0.06$ & $8.03 \pm 0.07$ \\
\hline
\end{tabular}




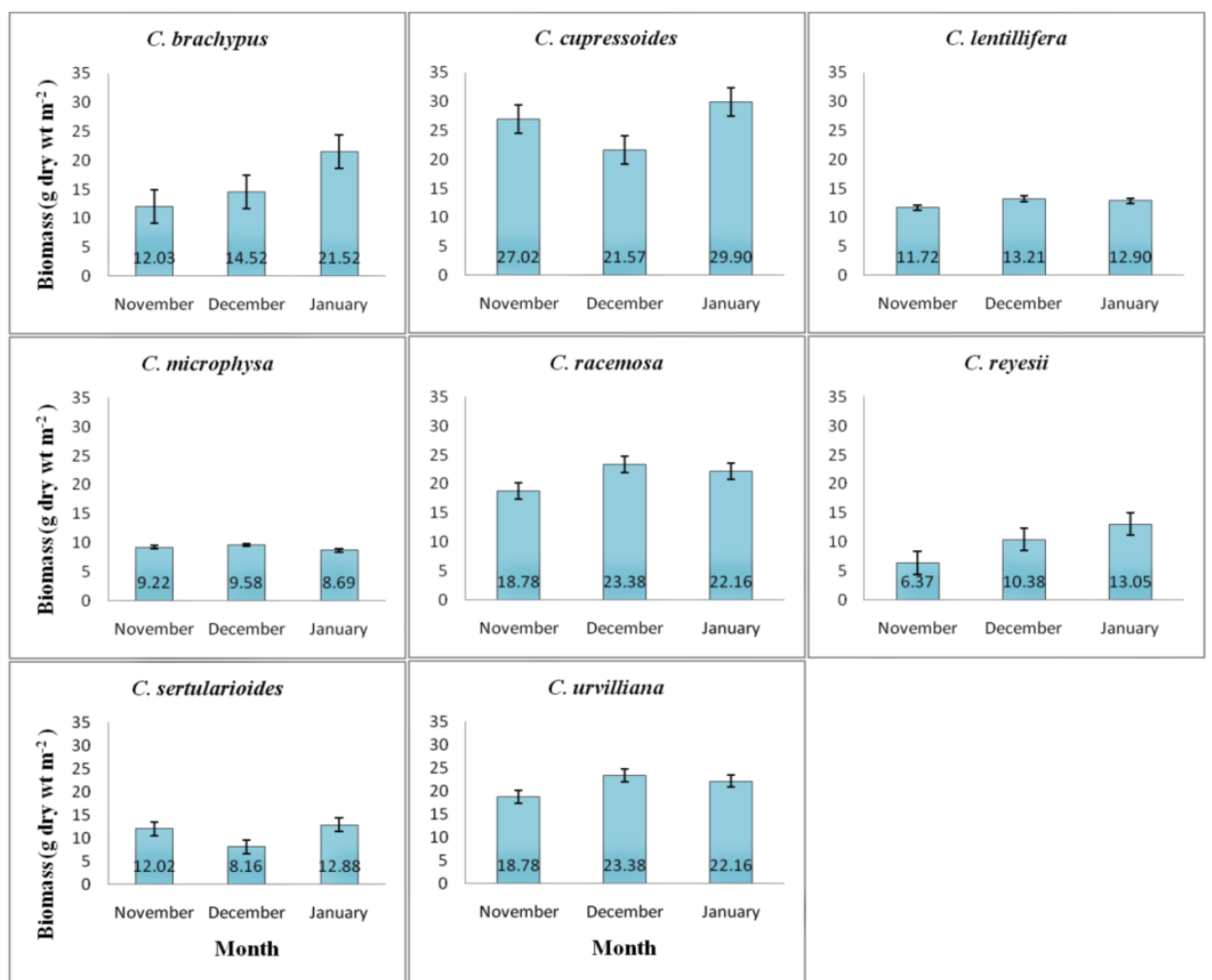

Figure 2. Mean \pm SE standing stock biomass of each Caulerpa species in the study site during the three-month sampling period. A. C. brachypus, B. C. cupressoides, C. C. lentillifera, D. C. microphysa, E. C. racemosa, F. C. reyesii, G. C. sertularioides, H. C. urvilliana.

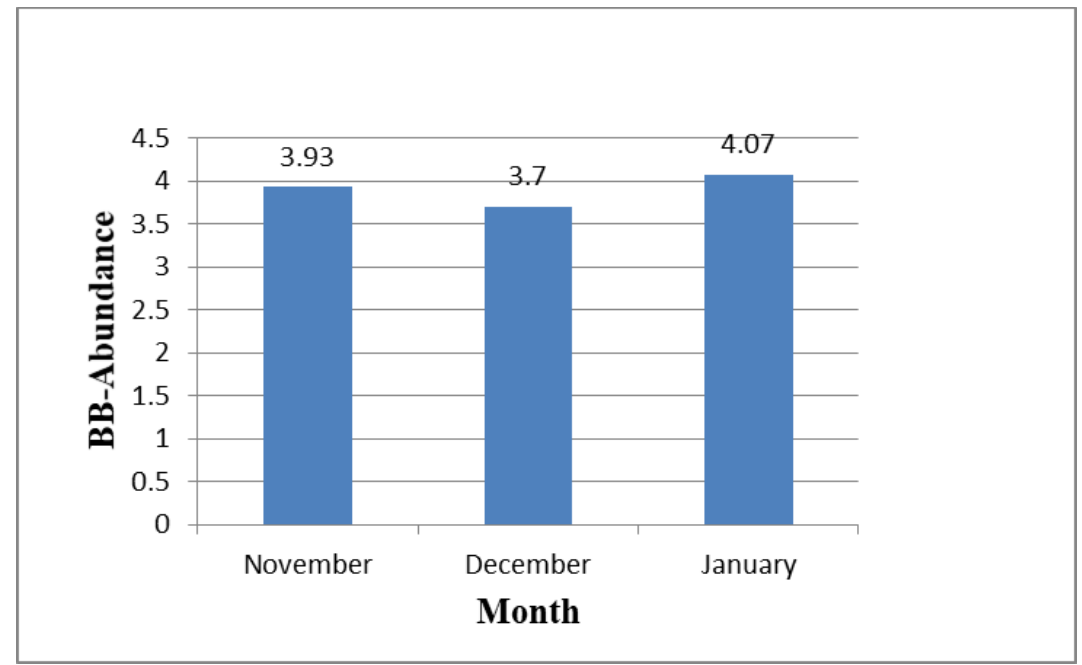

Figure 3. Mean ( \pm SE) of B-B abundance scores of Caulerpa (overall) between sampling months (November 2016-January 2017)

The relationship between biomass of Caulerpa species and the eight environmental variables was assessed using the multivariate Canonical Correspondence Analysis (CCA) following ter Braak \& Verdonschot (1995). Based on the CCA biplot, Axis 1 explained $52.4 \%$ of the variation in the abundance of the eight species, whereas Axis 2 explained 34.59\%.
However, an eigenvalue of 0.025 in Axis 1 indicate a relatively low gradient, with Axis 2 much weaker (0.016). It can be seen that of the eight environmental variables, four of which are positively correlated with the first axis (horizontal): $\mathrm{pH}$, water temperature, medium sand and gravel. The rest are negatively correlated with the first axis: coarse sand, fine sand, very fine sand, and 
salinity. C. cupressoides and $C$. racemosa were the most abundant during the study. It can be inferred that these species having scores of 0.174 and 0.302 in Axis 1 , respectively, were influenced by $\mathrm{pH}$, water temperature, and two types of substrate grain size, gravel and medium sand (Figure 6).

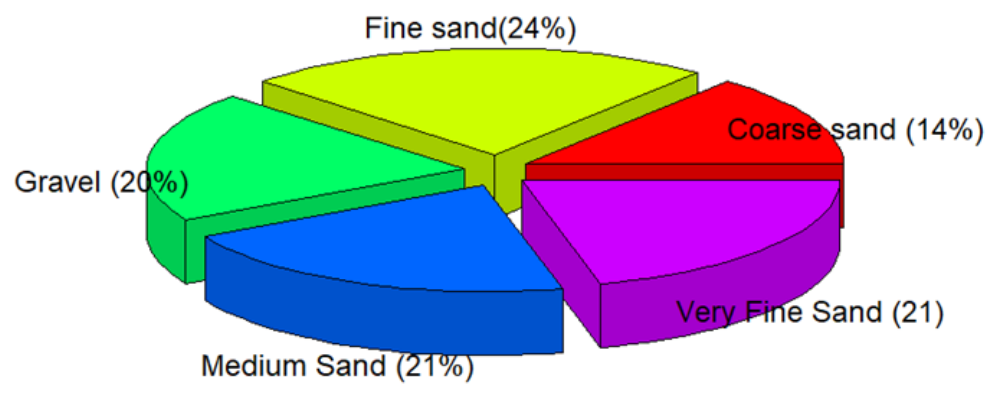

Figure 4. Type of substrates in the sampling sites

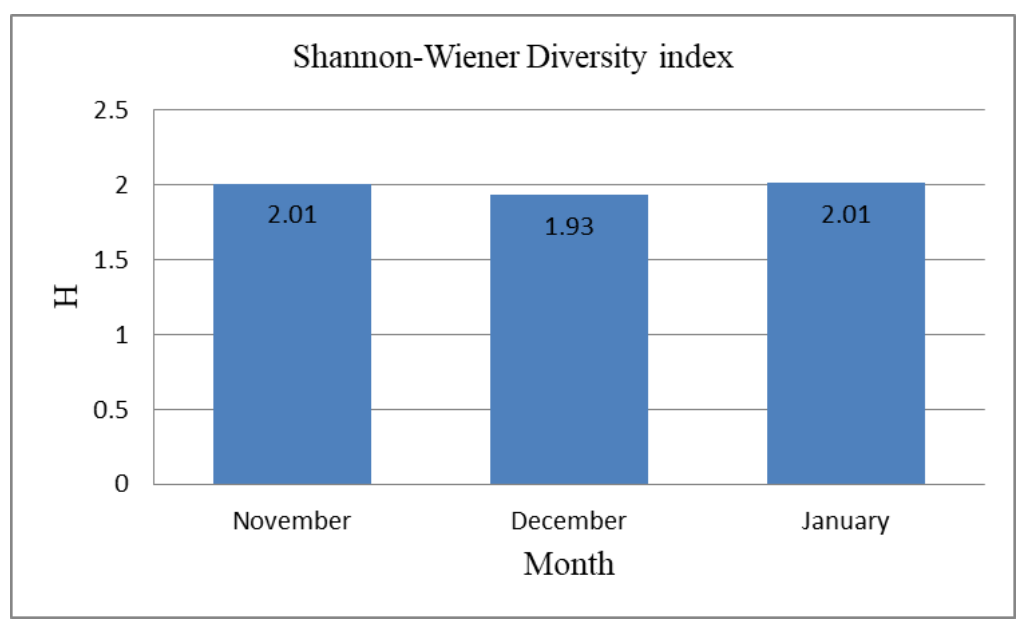

Figure 5. Shannon-Weiner Diversity Index between sampling months.

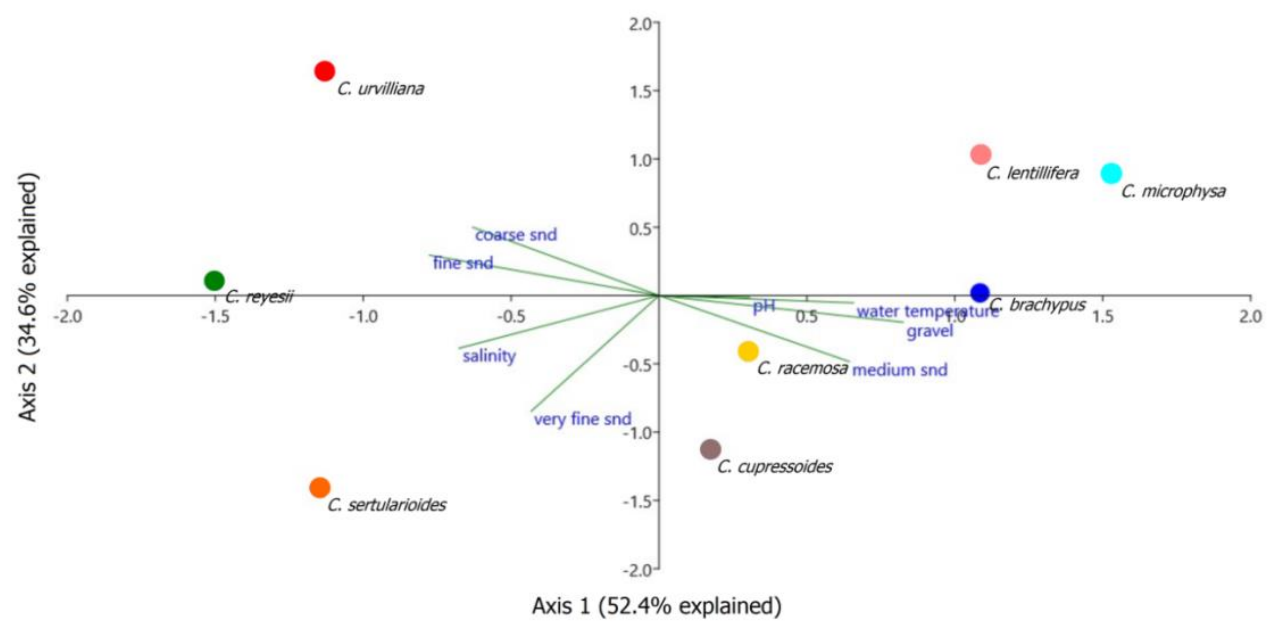

Figure 6. Canonical Correspondence Analysis (CCA) biplot showing the relationship of Caulerpa species and environmental parameters. 


\section{DISCUSSION}

After three months of sampling, eight species of Caulerpa were identified. These were $C$. brachypus, $C$. cupressoides, C. lentillifera, C. microphysa, C. racemosa, C. reyesii, $C$. sertularoides, and C. urvilliana (Plate 1). According to Meñez and Calumpong (1982), these species were commonly found in Siquijor, Philippines. The present study has fewer species count than the previous study by Calumpong (1984) which mentioned eleven species of Caulerpa, including C. taxifolia which may be found in deeper and sandy areas (Belsher \& Meinesz 1995; Thibaut et al 2004; Aplikioti et al 2016) while the present study focused only in the shallow areas. Moreover, there was limitation of the length of transect line used. For example, Calumpong (1984) extended up to $600 \mathrm{~m}$ from the mangrovelined shoreline. Given the limited sampling period, the following interpretations on standing stock biomass, cover, and diversity should be treated with caution.

The overall standing stock biomass in this study was relatively lower than the study conducted in the Mediterranean Sea by Thibaut et al. (2004). It has been considered that these macroalgal species were invasive in these areas due to their highly proliferative abilities (Boudouresque et al 1995; Klein \& Verlaque 2008; Cebrian \& Ballesteros 2009; Ruiz et al 2011; Papini et al 2013). In contrast, Calumpong (1984) reported a relatively lower standing stock biomass for $C$. racemosa. However, the present study obtained much higher values in the standing stock biomass. It has been reported that a decline in the harvest of $C$. racemosa occurred (Wagey \& Bucol 2014). This decline in harvest, driven by local price of lato, may have contributed to increased standing stock biomass. Moreover, their proliferative abilities may have also contributed to the observed increase. According to the locals, when Caulerpa thalli are carefully cut, this would lead to an abrupt increase in the abundance. This observation needs further investigation. According to Klein and Verlaque (2008), one way of vegetative multiplication by Caulerpa is through fragmentation. Fragmentation caused by these anthropogenic disturbances may able to survive for several days and may re-establish on a suitable substrate (Ceccherelli \& Piazzi 2001).

Braun-Blanquet cover abundance in this study showed that the genus Caulerpa occurred with the highest abundance throughout the sampling period. This means that Caulerpa were the dominant algal species present in the study site, although seagrasses (e.g. Enhalus acoroides) and sponges were also observed. This result is in agreement with the studies by Gab-Alla (2007) and Baldacconi and Corriero (2009) wherein Caulerpa dominates over Halophila stipulacea and sponge assemblages, respectively. This may be due to the competitive success of Caulerpa which is related to its specific characteristics which are its dispersal abilities (Klein \& Verlaque 2008; Prathep et al 2011), its tolerance to the lack of severe nutrient limitation (Delgado et al 1994) and its tolerance to wide temperature (Gacia et al 1996).

This study also showed a relatively strong correlation of the types of substrate or sediment that may have contributed to the distribution and abundance of Caulerpa (Fernández-García et al 2012; Sahayaraj et al 2014; Dean et al 2015). The Caulerpa species collected in the publication by Meñez and Calumpong (1982) include sand, mud, coral rubbles, and rocky substrate. This was also true according to the study by Fernández-García et al. (2012). However, there was preference over the different types of substrates (Infantes et al 2011; Pinna et al, 2011) with varying growth rates (Katsanevakis et al 2010). According to Piazzi et al. (2007), these sediments are considered as structural constituents of Caulerpa that could play a role in their proliferation. In the present study, $C$. cupressoides was the most abundant in sandy substrates. According to Williams (1984), $C$. cupressoides was able to take up nutrients from these types of sediments as an adaptation to nutrient-limited waters.

Throughout the sampling period, a consistent $\mathrm{H}^{\prime}$ index was observed. Although sampling was done for only three months. In contrast to other studies done elsewhere, which showed temporal variation (Tribollet \& Vroom, 2007; Mendoza \& Soliman, 2013; Kokabi et al 2016), the present study do not. The homogeneity of the environmental 
variables may have also accounted for this result.

Meanwhile, since there is no available data dealing with the molecular identification of $\mathrm{C}$. reyesii at present, it would be an essential subject matter to consider for future studies. This species was first identified from the sampling area in 1978 and identification through molecular phylogeny would possibly update the taxonomic classification of Caulerpa (Belton et al. 2014).

\section{CONCLUSIONS}

- A total of eight species of Caulerpa was identified throughout the sampling period. This study has also shown that the standing stock biomass of Caulerpa was the same throughout the sampling period. The highest standing stock biomass was obtained by $C$. cupressoides. Caulerpa community was also relatively diverse $\left(\mathrm{H}^{\prime}\right.$ index $\left.=1.7-2\right)$. Tropical shallow environments apparently provide all the requirements for a relatively diverse and abundant Caulerpa species. Water temperature, in particular, has greatly influenced the biomass and abundance of Caulerpa. Thus, when culturing these macroalgal species, water temperature as well as the percentage composition of sediments must be monitored well.

\section{Recommendations}

The increase in the standing stock biomass between the study in 1984 and the present study may have illustrated the prolific character of Caulerpa. However, more studies are still needed to fully understand these characteristics especially in the tropical regions. Other environmental parameters which are vital to the abundance and distribution of Caulerpa species were not included in this study. Thus, for future studies, the following environmental parameters (e.g. light intensity, wave exposure, and sediment and water nutrient content) must be included. It is also worthy to mention the effects between the competition of Caulerpa and seagrasses in the study site. The duration of the study should also be extended to at least one-year to cover temporal variation in the biomass and abundance of Caulerpa. Extending of transect lines or different zones must also be considered when sampling these Caulerpa community.

\section{Acknowledgements}

Foremost, we appreciate the local government unit (LGU) of Siquijor for allowing J.C. Llamas to conduct this study as part of his BSc thesis project. We would like to thank Dr. Stefano Draisma of the Prince of Songkla University, Thailand for confirming the identity of Caulerpa species. The Biology and Chemistry Departments of Negros Oriental State University (NORSU), Dumaguete City are also invaluable for allowing us to work and use their laboratory equipment. Mr. Noe M. Bucol and Nong Tonyo are deeply thanked for their patience and assistance during fieldwork. Moreover, J.C Llamas would like to thank Noe and his family for allowing him to stay at his residence while he was in Solong-on for the field survey.

\section{REFERENCES}

Aplikioti, M., Louizidou, P., Mystikou, A., Marcou, M., Stavrou, P., Kalogirou, S.,Tsiamis, K., Panayotidis, P., Küpper, F.C. 2016. Further expansion of the alien seaweed Caulerpa taxifolia var. distichophylla (Sonder) Verlaque, Huisman and Procacini (Ulvophyceae, Bryopsidales) in the Eastern Mediterranean Sea. Aquatic Invasions 11(1): 11-20.

Baldacconi, R., Corriero, G. 2009. Effects of the spread of the alga Caulerpa racemosa var. cylindracea on the sponge assemblage from coralligenous concretions of the Apulian coast (Ionian Sea, Italy). Marine Ecology 30:337-345.

Belton, G.S., Prud'homme van Reine, W.F., Huisman, J.M., Draisma, S.G.A., and Gurgel, C.F.D. 2014. Resolving phenotypic plasticity and species designation in the morphologically challenging Caulerpa racemosa-peltata complex (Caulerpaceae, Chlorophyta). Journal on Phycology 50: 32-54. 
Belsher, T. and Meinesz, A. 1995. Deepwater dispersal of the tropical alga Caulerpa taxifolia introduced into the Mediterranean. Aquatic Botany 51: 163-169.

Boudouresque, C.F., Meinesz, A., Ribera, M.A., and Ballesteros, E. 1995. Spread of the green alga Caulerpa taxifolia (Caulerpales, Chlorophyta) in the Mediterranean: possible consequences of a major ecological event. Scientia Marina 59, supl.(1): 21-29.

Bouiadjra, B.B., Taleb, M.Z., Marouf, A., Benkada, M.Y., and Riadi, H. 2010. First record of the invasive alga Caulerpa racemosa (Caulerpales, Chlorophyta) in the Gulf of Arzew (western Algeria). Aquatic Invasions 5 supplement (1): S97-S101.

Calumpong, H.P. 1984. Abundance and Harvest of Caulerpa racemosa (lato) at Siquijor Island, Central Visayas, Philippines. Silliman Journal 31 (1-4): 46-52.

Cebrian, E. and Ballesteros, E. 2009. Temporal and spatial variability in shallow-and deep water populations of the invasive Caulerpa racemosa var. cylindracea in the Western Mediterranean. Estuarine, Coastal and Shelf Science (83): 469-474.

Ceccherelli, G. and Campo, D. 2002. Different Effects of Caulerpa racemosa on Two Co-occurring Seagrasses in the Mediterranean. Botanica Marina (45): 71-76.

Ceccherelli, G. and Piazzi, L. 2001. Dispersal of Caulerpa racemosa fragments in the Mediterranean: lack of detachment time effect on establishment. Botanica Marina (44): 209-213.

Cevik, C., Yokes, M.B., Cavas, L., Erkol, L.I., Dirici, O.B., and Verlaque, M. 2007. First report of Caulerpa taxifolia (Bryopsidales, Chlorophyta) on the Levantine coast (Turkey, Eastern Mediterranean). Estuarine, Coastal and Shelf Science (74): 549556.
Cordero Jr., P.A. 1990. Philippine Algal Taxonomy: Past, Present, and Future. Culture and Use of Algae in Southeast Asia: 89-97.

Dean, A.J., Steneck, R.S., Tager, D., and Pandolfi, J.M. 2015. Distribution, abundance and diversity of crustose coralline algae on the Great Barrier Reef. Coral Reefs, doi: 10.1007/s00338-015-1263-5.

Delgado, O., Rodriguez-Prieto, C., Gacia, E., and Ballesteros, E. 1994. Nutrientlimited productivity of Caulerpa prolifera Agardh, an alien seaweed invading the North Western Mediterranean: Preliminary results. Proceedings of the 1st International Workshop on Caulepa prolifera GIS Posidonie, (CPGISP'94), Marseille: 295-299.

English, S., Wilkinson, C., and Baker, V. 1997. Survey Manual for Tropical Marine Resources 2nd Edition. Townsville, Australian Institute of Marine Science, 390p.

Fernández-García, C., Cortés, J., Alvarado, J.J., and Nivia-Ruiz, J. 2012. Physical factors contributing to the benthic dominance of the alga Caulerpa sertularioides (Caulerpaceae, Chlorophyta) in the upwelling Bahía Culebra, North Pacific of Costa Rica. Revista de Biología Tropical 60: 93107.

Gab-Alla, A.A.F.A. 2007. Ecological study on community of exotic invasive seaweed Caulerpa prolifera in Suez Canal and its associated macroinvertebrates. Journal of Applied Sciences 7: 679-686.

Gacia, E., Rodríguez-Prieto, C., Delgado, O., and Ballesteros, E. 1996. Seasonal light and temperature responses of Caulerpa taxifolia from the northwestern Mediterranean. Aquatic Botany 53: 215-225.

Guiry, M.D., Guiry, G.M. 2018. Algae Base. World-wide electronic publication, National University of Ireland, Galway. http://www.algaebase.org; Accessed on 21 February 2018. 
Hammer, Ø., Harper, D.A.T., Ryan, P.D. 2001. PAST: Paleontological Statistics software package for education and data analysis. Palaeontologia Electronica 9(1): 9.

Infantes, E., Terrados, J., Orfila, A. 2011. Assessment of substratum effect on the distribution of two invasive Caulerpa (Chlorophyta) species. Estuarine, Coastal and Shelf Science 9(1): 434441.

Iveŝa, L., Jaklin, A., Devescovi, M. 2006. Vegetation patterns and spontaneous regression of Caulerpa taxifolia (Vahl) C. Agardh in Malinska (Northern Adriatic, Croatia). Aquatic Botany 8(5): 324-330.

Jousson, O., Pawlowski, J., Zaninetti, L., Meinesz, A., Boudouresque, C.F. 1998. Molecular evidence for the aquarium origin of the green alga Caulerpa taxifolia introduced to the Mediterranean Sea. Marine Ecology Progress Series 172: 275-280.

Katsanevakis, S., Salomidi, M., Panou, A. 2010. Modelling distribution patterns and habitat preference of the invasive green alga Caulerpa racemosa in the Saronikos Gulf (Eastern Mediterranean). Aquatic Biology 10: 57-67.

Klein, J., Verlaque, M. 2008. The Caulerpa racemosa invasion: A critical review. Marine Pollution Bulletin 56: 205225.

Kokabi, M., Yousefzadi, M., Razaghi, M., Feghhi, M.A. 2016. Zonation patterns, composition and diversity of macroalgal communities in the eastern coasts of Qeshm Island, Persian Gulf, Iran. Marine Biodiversity Records 9: 111.

Manas, H.M., Deshmukhe, G., Venkateshwarlu, G., Chakraborty, S.K., Jaiswar, A.K., Pankajkumar, Mugaonkar, H., Dar, S.A. 2015. Morpological comparison of different Caulerpa J.V. Lamouroux species along Maharashtra and Gujarat coast, India. Indian Journal of Geo-Marine Sciences 44(5): 732-737.
Mendoza, A.B. Jr. Soliman V.S. 2013. Community Structure of Macroalgae of Lagonoy Gulf, Bicol Region, Philippines. Kuroshio Science 7: 4957.

Meñez, E.G., Calumpong, H.P. 1982. The Genus Caulerpa from Central Visayas, Philippines. City of Washington, Smithsonian Institution Press: 1-21.

Mueller-Dombois, D., Ellenberg, H. 1974. Aims and Methods of Vegetation Ecology. United States of America, John Wiley and Sons, Inc.

Nagappan, T. Vairappan, C.S. 2013. Nutritional and bioactive properties of three edible species of green algae, genus Caulerpa (Caulerpaceae). Journal of Applied Phycology 26: 1019-1027.

Papini, A., Mosti, S., Santosuosso, U. 2013. Tracking the origin of the invading Caulerpa (Caulerpales, Chlorophyta) with Geographic Profiling, a criminological technique for a killer alga. Biological Invasions, doi:10.1007/s10530-012-0396-5.

Piazzi, L., Balata, D., Foresi, L., Cristaudo, C., Cinelli, F. 2007. Sediment as a constituent of Mediterranean benthic communities dominated by Caulerpa racemosa var. cylindracea. Scientia Marina 71(1): 129-135.

Pinna, S., Bulleri, F., Mura, F., Sechi, N., Ceccccherelllli, G. 2011. Investigating on The Factors Responsible for Caulerpa racemosa Invasion. Biologia Marina Mediterranea. 18 (1): 280-281.

Prathep, A., Pongparadon, S., Darakrai, A., Wichachucherd, B., Sinutok, S. 2011 Diversity and distribution of seaweed at Khanom-Mu Ko Thale Tai National Park, Nakhon Si Thammarat Province, Thailand. Songklanakarin Journal of Science and Technology 33(6): 633640.

RStudio Team. 2015. RStudio: Integrated Development for R. RStudio, Inc., Boston, MA URL http://www.rstudio.com/. 
Ruiz, J.M., Marín-Guirao, L., BernardeauEsteller, J., Ramos-Segura, A., GarcíaMuñoz, R., Sandoval-Gil, J.M. 2011. Spread of the invasive alga Caulerpa racemosa var. cylindracea (Caulerpales, Chlorophyta) along the Mediterranean coast of the Murcia region (SE Spain). Animal Biodiversity and Conservation 34(1): 73-82.

Sahayaraj, K., Rajesh, S., Asha, A., Rathi, J.M., Raja P. 2014. Distribution and diversity assessment of the macroalgae at four southern districts of Tamil Nadu, India. Indian Journal of GeoMarine Sciences 43(4): 607-617.

Schembri, P.J., Barbara, J., Deidun, A., Lanfranco, E., Lanfranco, S. 2015. It was only a matter of time: occurrence of Caulerpa taxifolia (Vahl) C. Agardh var. distichophylla (Sonder) Verlaque, Huisman and Procaccini in the Maltese Islands (Chlorophyta, Ulvophyceae, Caulerpaceae). BioInvasions Records 4(1): 9-16.

Short, F.T., Coles, R.G. 2001. Global Seagrass Research Methods. Volume 33 of Developments in Aquaculture and Fisheries Science(362 of Jackson Estuarine Laboratory contribution.

Taft, R.A., Jones, C. 2001. Sediment Sampling Guide and Methodologies (2nd Edition). Columbus, Ohio, Environmental Protection Agency.

ter Braak, C.J.F. 1986. Canonical Correspondence Analysis: A New Eigenvector Technique for Multivariate Direct Gradient Analysis. Ecology 67(5): 1167-1179.

ter Braak, C.J.F., Verdonschot, P.F.M. 1995. Canonical correspondence analysis and related multivariate methods in aquatic ecology. Aquatic Sciences 57: 255-289.

Terrados, J. Ros, J.D. 1995. Temporal variation of the biomass and structure of Caulerpa prolifera (Forsskål) Lamouroux meadows in the Mar Menor lagoon (SE Spain). Scientia Marina 59(1): 49-56.

Thibaut, T., Meinesz, A., Coquillard, P. 2004. Biomass seasonality of Caulerpa taxifolia in the Mediterranean Sea. Journal of Aquatic Botany 80): 291-297.
Tribollet, A.D. Vroom, P.S. 2007. Temporal and spatial comparison of the relative abundance of macroalgae across the Mariana Archipelago between 2003 and 2005. Phycologia 46 (2): 187-197.

Trono, G.C. 1997. Field guide and atlas of the seaweed resources of the Philippines. Makati City, Philippines, 306p.

U.S. Army Corps of Engineers Jacksonville District .2009. Quality Assurance Systems Requirements. Retrieved from http://www.tidalmarshmonitoring.org/p df/1_CERP2009_SoilSedimentSamplin g_Chap07.pdf.

Verlaque, M., Afonso-Carrillo, J., GilRodríguez, M.C., Durand, C., Boudouresque, C.F., Le Parco, Y. 2004. Blitzkrieg in a marine invasion: Caulerpa racemosa var. cylindracea (Bryopsidales, Chlorophyta) reaches the Canary Islands (north-east Atlantic). Biological Invasions 6): 269-281.

Wagey, B.T., Bucol, A.A. 2014. A Brief Note of Lato (Caulerpa racemosa) Harvest at Solong-on, Siquijor, Philippines. Budidaya Perairan Januari 2(1): 46-51.

Williams, S.L. 1984. Uptake of sediment ammonium and translocation in a marine green macroalga Caulerpa cupressoides. Limnol. Oceanogr. 29(2): 374-379. 